\title{
Remaining Service Life Diagnostic Technology of Insulators for Power Distribution Equipment
}

\author{
Shinsuke Miki Member (Mitsubishi Electric Corporation) \\ Hiroshi Okazawa Non-member (Mitsubishi Electric Corporation) \\ Taketoshi Hasegawa Member (Mitsubishi Electric Corporation) \\ Sei Tsunoda Non-member (M-TEC Co., Ltd.) \\ Hiroshi Inujima Member (Graduate School of IPS, Waseda University)
}

\begin{abstract}
Keywords: remaining service life diagnosis, insulators, power distribution equipment, electric discharge, Mahalanobis-Taguchi
\end{abstract} method, chemical evaluation

To prevent an unexpected power outage resulting from an accident and to reduce capital investment, technology is needed for diagnosing the remaining service life of insulators for electric installations. Diagnostic techniques have been proposed for rotating machines, power transformers, and power cables. However, to date there is no effective diagnostic technique for power distribution equipment. This paper describes our novel remaining service life diagnostic technique for insulators, which are important parts involved in determining the service life of power distribution equipment.

New insulators for breakers, as well as those already used commercially, were sampled. In addition to chemical evaluations, surface resistivity was measured as reference data. Application of chemical evaluation and the Mahalanobis-Taguchi (MT) method enabled us to diagnose the insulators' degree of deterioration with great accuracy and nondestructively on-site, since a linear relationship existed between the diagnostic results of the chemical evaluation data by the MT method and the actual measurement results for surface resistivity. Figure 1 shows the concept chart of the remaining service life diagnostic method. Time was defined as the end of service life when electric discharge was initiated. The theory, which derives the threshold value of surface resistivity for electrical discharge initiation calculated from rated voltage, the form of an insulator, etc., was established and a remaining service life was presumed from the diagnostic results (B in Fig. 1) by the MT and the year ( $\mathrm{C}$ in Fig. 1) in which the master curve of service life and

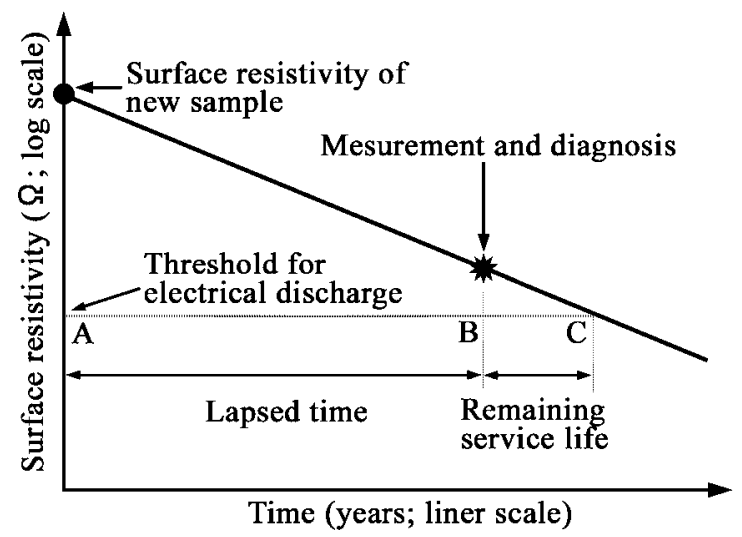

Fig. 1. Concept chart of remaining service life diagnostic method the threshold value intersect.

Table 1 shows the presumption results of remaining service lives of the insulators used commercially for 32 years. Surface resistivities for the insulators were obtained from the data of the ion concentration of the nitric acid, sulfuric acid and coloration $b$ by the MT method. The threshold value of surface resistivity for electrical discharge is $1.5 \times 10^{+9} \Omega$. The remaining service lives were calculated from surface resistivity obtained by the MT method, the threshold value, and the concept chart shown in Fig. 1. Because the remaining service lives were presumed to be between -0.9 and -1.1 years, it was thought that electric discharge had already been initiated.

Figure 2 shows the check examination results of electric discharge initiation. It was clarified that a remaining service life could be presumed by this technology because there was a good relationship between the check examination results of electric discharge initiation in the laboratory and the presumption results.

Table 1. Presumption results of remaining service life for insulators

\begin{tabular}{cccccc}
\hline Sample & $\begin{array}{c}\text { Nitric } \\
\text { acid ion } \\
\left(\mathrm{mg} / \mathrm{cm}^{2}\right)\end{array}$ & $\begin{array}{c}\text { Sulfuric } \\
\text { acid ion } \\
\left(\mathrm{mg} / \mathrm{cm}^{2}\right)\end{array}$ & $\begin{array}{c}\text { Color- } \\
\text { ation b } \\
(\text { a.u. })\end{array}$ & $\begin{array}{c}\text { Surface } \\
\text { resistivity } \\
(\Omega)\end{array}$ & $\begin{array}{c}\text { Remaining } \\
\text { service life } \\
(\text { year })\end{array}$ \\
\hline A & $1.02 \times 10^{-2}$ & $7.29 \times 10^{-2}$ & -0.53 & $6.31 \times 10^{+8}$ & -0.9 \\
B & $1.22 \times 10^{-2}$ & $6.43 \times 10^{-2}$ & -0.34 & $7.74 \times 10^{+8}$ & -0.8 \\
C & $1.14 \times 10^{-2}$ & $9.08 \times 10^{-2}$ & -0.48 & $3.89 \times 10^{+8}$ & -1.1 \\
\hline
\end{tabular}

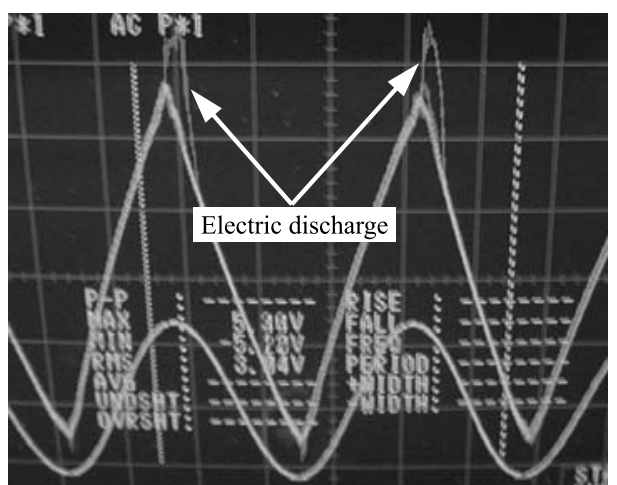

Fig. 2. Check examination results of electric discharge initiation 


\section{受配電設備絶縁物の余寿命診断技術}

$\begin{array}{lllll}\text { 正 員 三木 伸介* } & \text { 非会員 岡澤 } & \text { 周** } \\ \text { 正 員 長谷川武敏* } & \text { 非会員 角田 } & \text { 誠*** } \\ \text { 正 員 犬島 浩*** } & & & \end{array}$

\section{Remaining Service Life Diagnostic Technology of Insulators for Power Distribution Equipment}

Shinsuke Miki*, Member, Hiroshi Okazawa**, Non-member, Taketoshi Hasegawa*, Member, Sei Tsunoda***, Non-member, Hiroshi Inujima****, Member

We have developed a remaining service life diagnostic technology for insulators, which are important parts involved in determining the service life of power distribution equipment. Application of chemical evaluation and the Mahalanobis-Taguchi method enabled us to diagnose the insulators' degree of deterioration with great accuracy and nondestructively on-site. The theory, which derives the threshold value of surface resistivity for electric discharge initiation calculated from rated voltage, the form of an insulator, etc., was established and a remaining service life was presumed from the diagnostic results by the MT method and the year in which the master curve of service life and the threshold value intersect. It was clarified that a remaining service life could be presumed by this technology because there was a good relationship between the check examination results of electric discharge initiation in the laboratory and the presumption results.

キーワード : 余寿命診断, 絶縁物, 受配電設備, 放電, マハラノビス・タグチ法, 化学的評価

Keywords: remaining service life diagnosis, insulators, power distribution equipment, electric discharge, Mahalanobis-Taguchi method, chemical evaluation

\section{1. はじめに}

受配電設備は電気エネルギーを工場や建物へ供給する役 目を負っている設備であり，長期間にわたり信頼性，安定 性を確保して稼動することが要求される。現在，市場で運 転している遮断器等の受配電設備の大半が 1960 年代から 1970 年代の高度成長期に設置され，一般的に言われる電気

\footnotetext{
* 三菱電機 (株) 先端技術総合研究所

干 661-8661 尼崎市塚口本町 8-1-1

Advanced Technology R\&D Center, Mitsubishi Electric Corporation 8-1-1, Tsukaguchi-honmachi, Amagasaki 661-8661

** 三菱電機 (株) 受配電システム製作所

干763-8516 丸亀市蓬莱町 8

Power Distribution System Center, Mitsubishi Electric Corporation 8, Horai-cho, Marugame 763-8516

*** (株) エムテック

干 532-0003 大阪市淀川区宮原 3-3-31

M-TEC Co., Ltd.

3-3-31, Miyahara, Yodogawa-ku, Osaka 532-0003

**** 早稲田大学大学院 情報生産システム研究科

干 808-0135 北九州市若松区ひびきの 2-7

Graduate School of IPS, Waseda University

2-7, Hibikino, Wakamatsu-ku, Kita-Kyushu 808-0135
}

機器の寿命領域に到達しつつある。特に高圧電気設備で絶 縁劣化により電気的トラブルが発生すると, 生産損失や設 備補修など工場や建物に与える影響が非常に大きくなるた め, 適切な設備更新が必要となる。

一方，世界経済のグローバル化等による競争激化のため 設備投資の抑制や固定費削減が必須となり，既存設備の適 切な更新時期を判定可能な余寿命診断技術が望まれている。 回転機, 変圧器, 及び高圧ケーブル等の高圧電気設備の余 寿命診断方法 ${ }^{(1)}$ (7) は各種提案されているが, 受配電設備に 対する有効な診断方法はないのが現状である。

本論文では受配電設備の寿命を決定する重要部品である 絶縁物に着目し, 余寿命診断技術を開発した。受配電設備 は放電の発生を許容していないので，放電が発生した時点 を寿命と定義した。余寿命は，（1）品質工学の 1 手法であ るマハラノビス・タグチ $(\mathrm{MT})$ 法を適用し絶縁物表面のイ オン付着量等から算出した劣化度 (表面抵抗率), (2) 絶縁 物の形状等から導出した放電が発生する表面抵抗率（放電 閾值), 及び ( 3 ) 絶縁物の経年劣化直線から推定した。実験 室で行った電圧印加による放電発生の確認試験と余寿命推 定結果に相関性があり，本手法で受配電設備絶縁物の余寿 
命診断が可能であることを確認したので，その詳細を報告 する。

\section{2. 寿命の定義と開発課題}

〈2・1〉寿命の定義 絶縁物の環境劣化に着目し余寿 命診断技術を開発した。我々はポリエステル樹脂，炭酸力 ルシウム, 及びガラス繊維等からなる絶縁物について, 環境 劣化の主要因である表面抵抗率低下のメカニズムを解明し てきた ${ }^{(8)(9)}$ 。劣化メカニズム（図 1）は以下の通りである。

(1) 大気中の $\mathrm{NOx}$ (酸性ガス) が硝酸 $\left(\mathrm{HNO}_{3}\right)$ にな り，絶縁物の充填材である炭酸カルシウム $\left(\mathrm{CaCO}_{3}\right)$ と反 応して硝酸カルシウム $\left(\mathrm{Ca}\left(\mathrm{NO}_{3}\right)_{2}\right)$ が生成する。

（2）硝酸カルシウムは潮解性のイオン性化合物である ので, 吸湿した水に溶け込みイオン化して絶縁物の表面抵 抗率を低下させる。

SOx（酸性ガス）の場合も同様に硫酸カルシウムが生成 することにより，表面抵抗率が低下する。

このように潮解性物質による表面抵抗率の低下が起因と なり，ある一定值以下の表面抵抗率になると放電が発生す るが, 受配電設備は発電機等と異なり放電の発生を許容し ていない。また，放電発生以後は劣化のスピードが加速し 短絡事故の危険が増大するが，設備更新は適切な更新計画 が必要になるため, 診断実施から更新まで数年の期間を要 する。以上から，本報では放電の発生が開始する絶縁物の 劣化度 (表面抵抗率) を寿命の閾值 (放電閾値) と定義した。

$\langle\mathbf{2} \cdot \mathbf{2}\rangle$ 開発課題 絶縁物の劣化診断は絶縁抵抗測定や

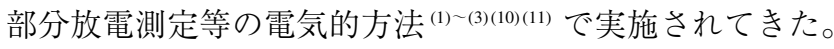
機器の設置現場ではこれらの方法は湿度や電磁波の影響を 強く受けるため, 測定する季節や時間により結果が大きく 異なる。また, 電気的な異常を検出するため, 検出可能な 範囲は約 $10^{+9} \Omega$ 以下の絶縁抵抗あるいは放電発生以後の 状態等であり，異常診断の域をでていない。余寿命診断技 術を確立するためには，新品から放電発生までの任意の時 間に㧍ける絶縁物劣化度の明確化, 絶縁劣化の湿度依存性 の明確化，及び定格電圧や絶縁物形状等を考慮した間值の

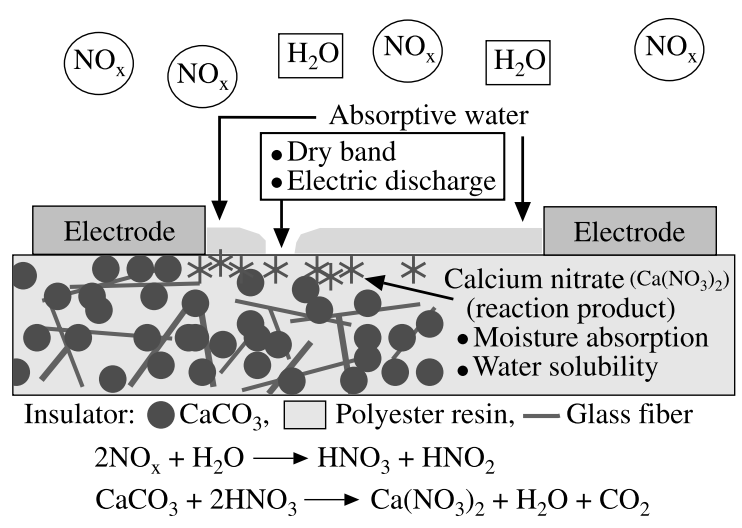

図 1 絶縁物の劣化メカニズム

Fig. 1. Deterioration mechanisim of insulator.
明確化が必要となると考えられる。本報では以上の課題に 取り組み，余寿命診断技術を開発した。

\section{3. サンプルと評価方法}

受配電設備絶縁物の新品と市場使用品をサンプルとした。 絶縁物はポリエステル樹脂, 炭酸カルシウム, 及びガラス 瀻維等からなる有機絶縁物である。市場使用品の使用年数 は 8〜40 年である。絶縁物の新品と市場使用品の評価は, 色彩 - 光沢測定, 成分分析, イオン付着量分析, 及び表面 抵抗率測定を行った (9)。色彩, 光沢は絶縁物の表面を直接 測定した。成分分析は表面層をサンプリングし赤外分光光 度計により分析した。イオン付着量分析は純水を含ませた 万紙を絶縁物表面に約 1 分間押し当て, 付着イオンをろ紙 に回収してイオンクロマトグラフで分析した。表面抵抗率 測定は絶縁物の表面に櫛形電極を蒸着し，温度，湿度を制 御した条件下で行った。

\section{4. 結果と考察}

〈4・1〉 MT 法による絶縁物の劣化診断 湿度や電磁 波ノイズの影響を受けないイオン付着量等の化学的方法で 絶縁物を評価し, 評価結果を MT 法 ${ }^{(12)} に よ り$ 判断するこ とで受配電設備の高精度な絶縁劣化診断を可能にした ${ }^{(8)(9) 。 ~}$ MT 法とは様々な情報を総合して1つの物差しで判断する 技術である。正常なサンプルのデータから診断の基準とな るデー夕群（基準空間）を作成して, 基準空間からの靟離 度で診断対象の劣化度を判断する（図 2)。乘離度は従来か ら統計学の分野で使用されているマハラノビスの距離(12)(13) を用いて表す。

新品絶縁物のデー夕を基準空間として市場使用品の劣化 度を MT 法で診断し，表面抵抗率の実測值（湿度 RH50\%） と比較した結果を図 3 に示す。マハラノビスの距離と表面 抵抗率は良好な相関（相関係数 $0.96 ） を$ を示すことから, 機 器の設置現場で精度良く診断することが困難な絶縁抵抗測 定等の代わりに，MT 法を適用することにより新品を含め た様々な劣化度の絶縁物に対して診断が可能であることを 明確にした。

$\langle\mathbf{4} \cdot \mathbf{2}\rangle$ 表面抵抗率低下の時間依存性 MT 法による絶

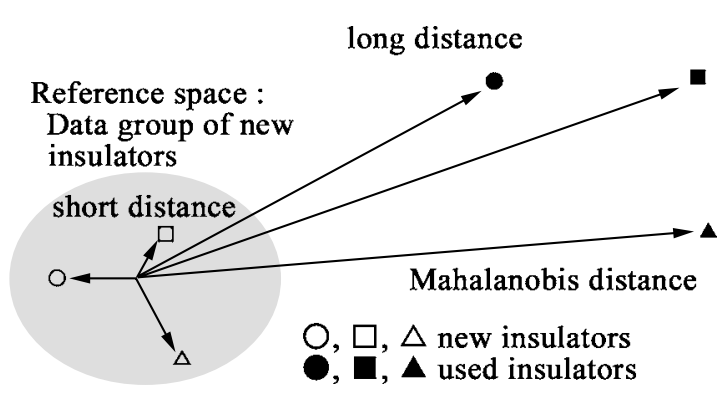

図 2 MT 法による絶縁劣化診断の概念

Fig. 2. Concept chart of deterioration diagnosis of insulators using the MT method. 


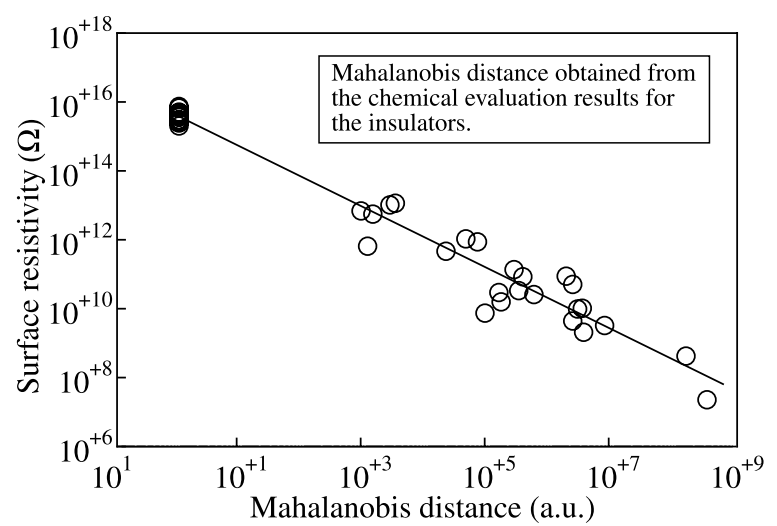

図 3 マハラノビスの距離と表面抵抗率の関係

Fig. 3. Relationship between Mahalanobis distance and surface resistivity.

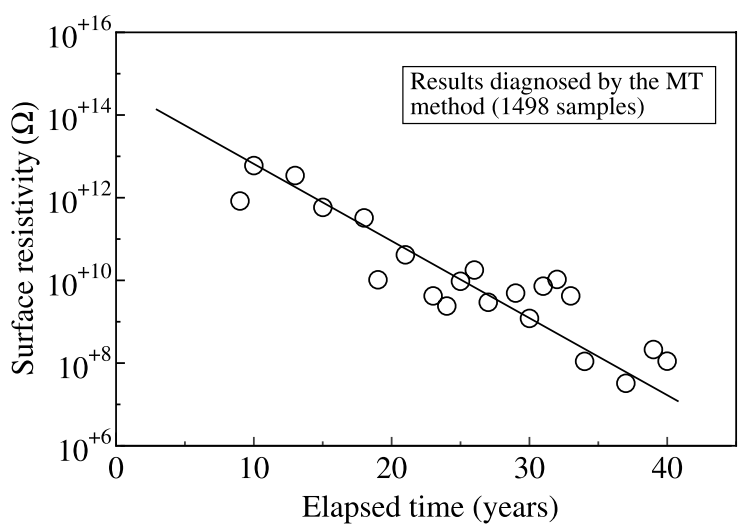

図 4 使用年数と表面抵抗率の関係

Fig. 4. Relationship between elapsed time and surface resistivity.

縁物の劣化診断結果（表面抵抗率）と使用年数の関係を求 め, 表面抵抗率の経年劣化傾向を明確にした。結果を図 4 に示す。横軸は使用年数，縦軸は湿度 50\%RH に扔ける表 面抵抗率であり, 各使用年数に対して表面抵抗率の平均值 をプロットしている。これらのデータは NOx 等の環境要 因による誤差が含まれているが, サンプル数は 1498 件であ り, 表面抵抗率の経年劣化傾向を把握するには充分なサン プル数であると考えられる。この結果から, 経過年数のリ ニアー值と表面抵抗率の対数值は直線関係にあることが分 かる。よって, 新品時と診断時の表面抵抗率（対数值）を 結んだ直線が放電閾值と交差する年数を求めることにより 余寿命を推定できる。

余寿命診断方法の概念図を図 5 に示す。新品時を $A$, 診 断時の使用年数を $B$, 新品時と診断時の表面抵抗率（湿度 $50 \% \mathrm{RH})$ を結んだ直線が放電閾值と交差する年数を $C$ と すると, $B C$ が余寿命年数に相当する。診断時の使用年数 $(=A B)$ は既知であるため $A$ と $B$ での表面抵抗率の比から $B C$ の年数を算出することで, 湿度 $50 \% \mathrm{RH}$ に扔ける余寿 命を求めることができる。

\section{$\langle\mathbf{4} \cdot \mathbf{3}\rangle$ 絶縁物劣化度の湿度依存性 絶縁物の表面抵}

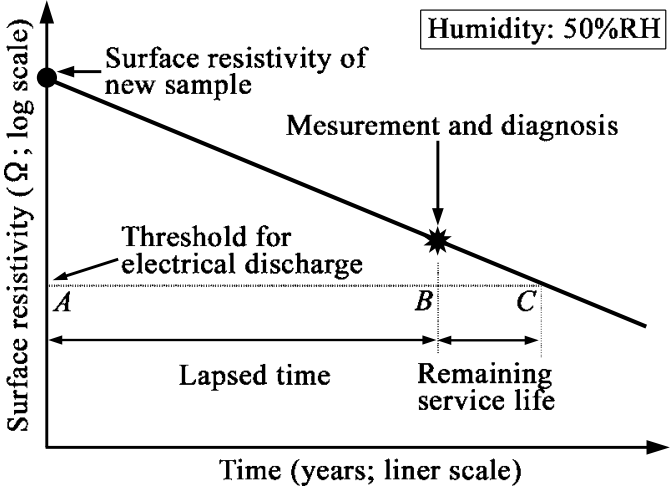

図 5 余寿命診断方法の概念図

Fig. 5. Concept chart of remaining service life diagnostic method.

抗率は湿度の影響を大きく受けるが，任意の湿度での表面 抵抗率を求めることができれば様々な環境に設置されてい る機器の診断に対応可能となる。MT 法による絶縁診断で 求まる表面抵抗率（図 3）は湿度 50\%RH での值であるの で, 表面抵抗率の湿度依存性を数式化すれば任意の湿度で の表面抵抗率を求めることができる。市場で使用されてい た絶縁物の表面抵抗率を各種湿度で実測し, 表面抵抗率の 湿度依存性を求めた。

$\langle\mathbf{4} \cdot \mathbf{3} \cdot \mathbf{1}\rangle \quad$ ガウス分布関数によるフィッティングの試み 表面抵抗率 (対数值) の湿度依存性について検討するた めに，(1)，(2) 式で表されるガウス分布関数によるフィッ ティングを試みた。両式ともここで提案する経験式である。 式中のパラメーター $\rho$ は表面抵抗率， $\rho_{0}$ は湿度 $100 \% \mathrm{RH}$ での表面抵抗率, $n$ は湿度 $0 \% \mathrm{RH}$ に扮ける表面抵抗率と $\rho_{0}$ の対数差 $\left(n=\log \rho-\log \rho_{0}\right), \sigma$ はガウス分布関数の偏差, $m$ は表面抵抗率が平均值をとるときの湿度をそれぞれ仮定 したものである。hは測定時の湿度（\%RH）である。

$$
\begin{aligned}
& \log \rho=\log \rho_{0}+n \psi(h) \ldots \ldots \ldots \ldots \ldots \ldots . . \\
& \psi(h)=\frac{1}{\sqrt{2 \pi} \sigma} \int_{-\infty}^{h} \exp \left(-\frac{(m-h)^{2}}{2 \sigma^{2}}\right) d h .
\end{aligned}
$$

図 6 に市場で使用されていた絶縁物の表面抵抗率測定結果 とフィッティングしたガウシアン曲線を示す。いずれの曲 線も測定点に良くフィットしていることから，ガウス分布 関数を用いることで任意の湿度に打ける表面抵抗率を算出 できることが分かる。

$\langle\mathbf{4} \cdot \mathbf{3} \cdot \mathbf{2}\rangle$ 理論的考察 ここで適用した (1)，(2) 式は あくまでも経験的なものであるが, 劣化デー夕の整理に有用 であることが分かったので，この式を拡散方程式と NernstEinstein の式を使って説明する。拡散方程式（(3) 式）は以 下で表され, $c$ は濃度, $x$ は拡散距離, $D$ は拡散定数である。

$$
\frac{\partial c}{\partial t}=D \frac{\partial^{2} c}{\partial x^{2}}
$$

(3) 式の基本解の積分形（(4) 式）はガウス分布関数となる。 $t$ は時間である。 


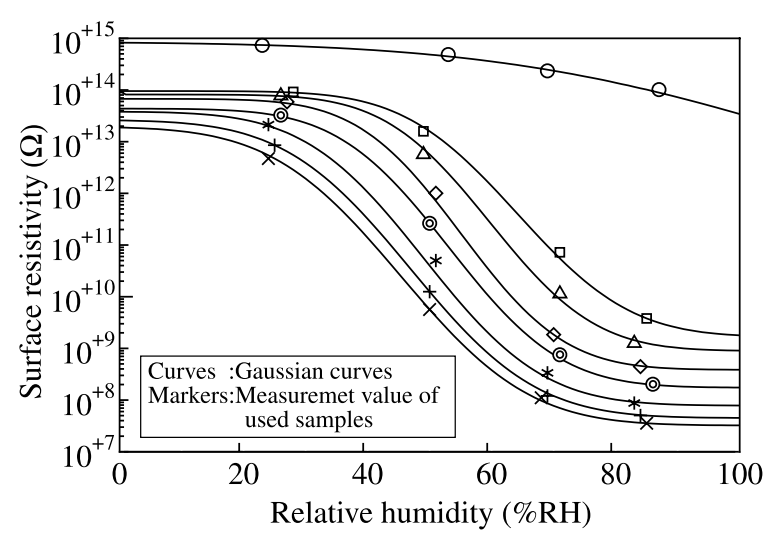

図 6 相対湿度と表面抵抗率の関係

Fig. 6. Relationship between Relative humidity and surface resistivity.

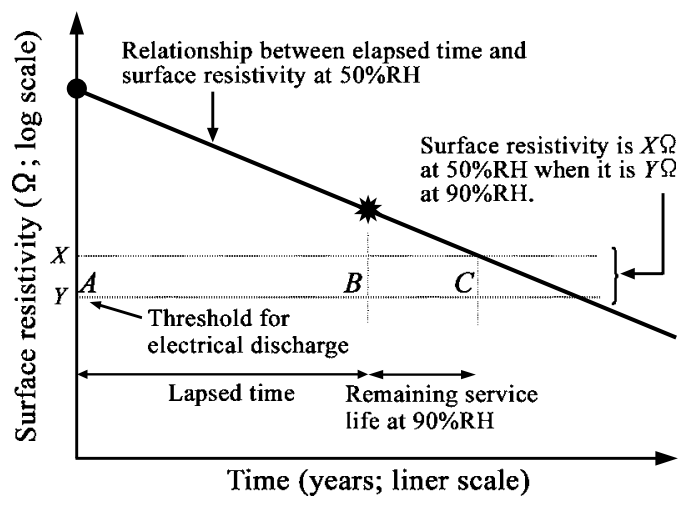

図 7 90\%RH での余寿命診断方法の概念図

Fig. 7. Concept chart of remaining service life diagnostic method at $90 \%$ RH.

$$
C_{(t, x)}=\frac{1}{\sqrt{4 \pi D t}} \int_{-\infty}^{x} \exp \left(-\frac{x^{2}}{4 D t}\right) d x
$$

一方, イオンの関与する導電率と拡散定数の関係は, NernstEinsteinの式（(5) 式）で表される。

$$
\int \partial s=\frac{q^{2} D}{k T} \int \partial N
$$

$s$ は導電率, $N$ はキャリア数, $q$ は電荷, $k$ はボルッマン定 数, $T$ は絶対温度である。ここで $\int \partial N$ を $C_{(t, x)}$ に置き換え ると, $\int \partial s=\int \partial(1 / \rho)=\log \rho$ であるから，(5) 式は (4) 式 を使って (6) 式で表される。

$$
\log \rho=\frac{q^{2} D}{k T} \frac{1}{\sqrt{4 \pi D t}} \int_{-\infty}^{x} \exp \left(-\frac{x^{2}}{4 D t}\right) d x
$$

(6) 式は形の上で (1), (2) 式と同じでガウス分布関数になっ ている。このことから経験式の (1), (2) 式は，イオン伝導 を記述するための少なくとも必要条件は満たしているとい える。

以上より，ある湿度における絶縁物の表面抵抗率が分か
Dry band(Discharge gap)

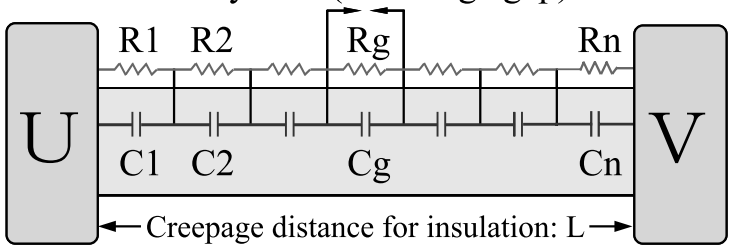

図 8 シンチレーション放電等価回路

Fig. 8. Equivalent circuit model for scintillation electrical discharge.

れば，任意の湿度における表面抵抗率を算出できることが 分かる。

前述の通り, MT 法による絶縁診断で求まる表面抵抗率 （図 3）は湿度 50\%RH での值である。湿度 $90 \% \mathrm{RH}$ での余 寿命を求めるためには図 7 に示したように実施する。湿度 $90 \% \mathrm{RH}$ で放電が発生するときの表面抵抗率 $Y \Omega$ になり, 湿度 $50 \% \mathrm{RH}$ では $X \Omega$ であるとすると, 図 7 において湿度 $90 \% \mathrm{RH}$ での放電閾値は $X \Omega$ となる。湿度 $90 \% \mathrm{RH}$ に対す る放電閾值 $X \Omega$ と直線が交差する年数を求めることにより, 湿度 $90 \%$ RH での余寿命を算出する。

$\langle\mathbf{4} \cdot \mathbf{4}\rangle \quad$ シンチレーション放電開始式による放電閾值

$\langle 4 \cdot 4 \cdot 1\rangle \quad$ シンチレーション放電開始式の導出 絶縁 物の電気的等価回路を図 8 に示す。図 8 において, 長さ $L$ の絶縁物に電圧 $V$ が印加されている状態で, 絶縁物の単位 長さ当たりの静電容量を $C 1 \sim C n$, 表面抵抗を $R 1 \sim R n$, ド ライバンドにおける絶縁物の静電容量を $C g$, 及び表面抵抗 を $R g$ と表している。ドライバンド部のインピーダンス $Z d$ と他の部分の単位長さ当たりのインピーダンス $Z p$ はそれ ぞれ (7) 式と (8) 式で表されることから, 課電されている絶 縁物全体のインピーダンス $Z$ は $Z=Z d+Z p \cdot n$ より (9) 式 となる。(9) 式の $n$ は絶縁物を単位長さで区切ったときの 個数であり, 絶縁物の沿面距離に比例する。

$$
\begin{aligned}
& Z d=\frac{R g / \omega C g}{\sqrt{R g^{2}+(1 / \omega C g)^{2}}} \cdots \ldots \ldots \ldots \ldots \ldots \ldots \ldots \ldots \ldots \ldots \ldots \ldots \\
& Z p=\frac{R n / \omega C n}{\sqrt{R n^{2}+(1 / \omega C n)^{2}}} \cdots \ldots \ldots \ldots \ldots \ldots \\
& Z=\frac{R g / \omega C g}{\sqrt{R g^{2}+(1 / \omega C g)^{2}}}+\left(\frac{R n / \omega C n}{\sqrt{R n^{2}+(1 / \omega C n)^{2}}}\right) n
\end{aligned}
$$

ここで, 絶縁物表面でシンチレーション放電が発生する 条件を計算する。図 8 に示されるドライバンド部の表面抵 抗 $R g$ は十分高いから, 絶縁物表面の電位分担は静電容量 $C g$ によるインピーダンスで決定されるため, $Z$ は (10) 式の ようにで近似できる。絶縁物に課電されている電圧 $V$ とド ライバンドに加わる電圧 $v g$ の関係は (11) 式で与えられる。

$$
Z \fallingdotseq \frac{1}{\omega C g}+\left(\frac{R n / \omega C n}{\sqrt{R n^{2}+(1 / \omega C n)^{2}}}\right) n
$$




$$
\begin{aligned}
v g & =V\left(\frac{Z d}{Z_{d}+Z p n}\right) \\
& =V\left(\frac{1}{\omega C g} /\left(\frac{1}{\omega C g}+\left(\frac{R n / \omega C n}{\sqrt{R n^{2}+(1 / \omega C n)^{2}}}\right) n\right)\right)
\end{aligned}
$$

ドライバンドのギャップ長を $g$ とすると, シンチレーショ ン放電開始電圧は $g$ に依存するため $v i(g)$ と表すことができ る。 $v g$ が $v i(g)$ を越える印加電圧 $V$ の条件を求めれば， シ ンチレーション放電開始電圧 $V i$ が (12) 式のように計算で きる。

$$
V i=\omega C g\left(\frac{1}{\omega C g}+\left(\frac{R n / \omega C n}{\sqrt{R n^{2}+(1 / \omega C n)^{2}}}\right) n\right) v i(g)
$$

$C g$ も同様にギャップ長 $g$ に依存する。vi(g) は, いわゆる パッシェンの火花開始電圧で与えられ, 大気圧空気の $v i(g)$ は (13) 式で近似できる ${ }^{(14)}$ (13) 式からドライバンドのギャッ プ長 $g$ が $0.0076 \mathrm{~mm}$ の場合にシンチレーション放電開始電 圧 $v i$ が $235 \mathrm{~V}$ になる。すなわち $235 \mathrm{~V}$ の電圧が $0.0076 \mathrm{~mm}$ の微小ギャップに印加された場合に放電が開始する。

$$
v i=235 \times 10^{+0.37 \mid\left(\left.\log \left(\frac{t}{0.0076}\right)\right|^{+1.53}\right.}
$$

以上より絶縁物の形状, 誘電率, 沿面距離, 周波数及び課 電電圧から単位長さ当たりの表面抵抗 $R n$ (=表面抵抗率) に対してギャップ長 $g$ とシンチレーション放電開始電圧 $V i$ との関係が分かるため，ある課電電圧で放電が開始する表 面抵抗率 (放電閾值) を求めることができる。

$\langle\mathbf{4} \cdot \mathbf{4} \cdot \mathbf{2}\rangle$ IEC 設計基準值, 污損耐圧試験結果と放電閾 值との比較 沿面距離（污損漏洩長）を規定する IEC 設 計基準值 (IEC815)，污損耐圧試験（污損度：等価塩分付 着量 $\left.0.03 \mathrm{mg} / \mathrm{cm}^{2}\right)$ による実測耐電圧值, 及びシンチレー ション放電開始式で求まる放電閾值を図 9 に示す。この放 電閾值は IEC 設計基準值, 污損耐電圧值と相関があること から，シンチレーション放電開始式で求まる放電閾值は有 効であることが確認できた。

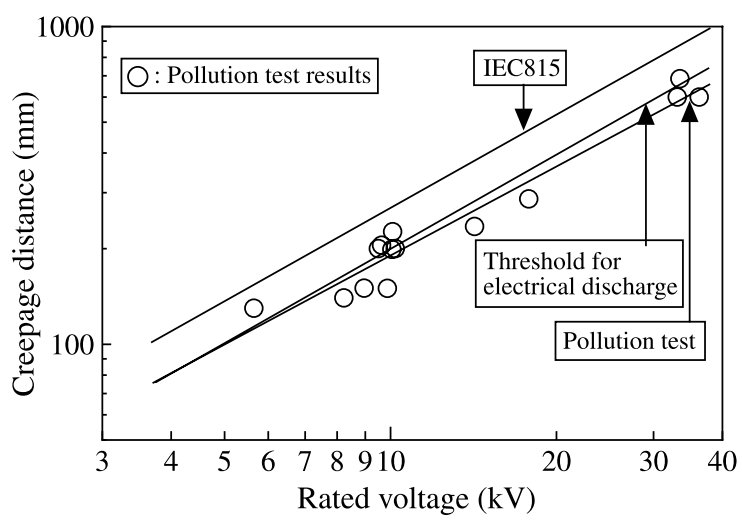

図 9 シンチレーション放電閾值

Fig. 9. Threshold for scintillation electrical discharge. $\langle\mathbf{4} \cdot \mathbf{5}\rangle \quad$ 診断手順のまとめ＼cjkstart絶縁物のイオン付着濃度等 の測定から余寿命年数の算出までの手順を以下にまとめた。

（1）絶縁物の化学的評価と MT 法による絶縁劣化診断 絶縁物のイオン付着濃度等の測定結果を MT 法で解析し, マハラノビスの距離を求める。予め求めていたマハラノビ スの距離と表面抵抗率の相関関係から, 表面抵抗率を算出 する。

（2）絶縁余寿命の推定新品時と診断時の表面抵抗 率を結び, 湿度 50\%RH での表面抵抗率低下の時間依存性 直線を得る。絶縁物の形状, 誘電率, 電圧等から診断対象 絶縁物に対して放電閾值を求める。放電閾值と直線の交差 する年数を求めることにより，余寿命を算出する。

以上は湿度 50\%RH での余寿命推定手順であるが，例え ば湿度 $90 \%$ RH での余寿命を求めたい場合は, 湿度 $90 \% \mathrm{RH}$ に対する放電閾值と直線が交差する年数を求めることによ り，湿度 $90 \% \mathrm{RH}$ での余寿命を算出する。

\section{$\langle\mathbf{4} \cdot \mathbf{6}\rangle$ 余寿命診断技術の検証}

$\langle\mathbf{4} \cdot \mathbf{6} \cdot \mathbf{1}\rangle$ 絶縁物余寿命の推定 新日本石油（株）水 島精油所殿からご提供頂いた受配電設備（幅 $80 \mathrm{~cm} \times$ 奥行 $200 \mathrm{~cm} \times$ 高さ $230 \mathrm{~cm}$ ) 絶縁物について, 湿度 $100 \% \mathrm{RH}$ で の余寿命を推定した。絶縁物はポリエステル絶縁物（図 10） で, 大きさは横 $58.5 \mathrm{~cm} \times$ 縦 $12.0 \mathrm{~cm} \times$ 厚さ $1.2 \mathrm{~cm}$ である。 サンプル数は 3 個, 使用年数は 32 年, 定格電圧は $3.45 \mathrm{kV}$ である。3 個とも同一形状で，湿度 $100 \% \mathrm{RH}$ における新品 時の表面抵抗率は $1.0 \times 10^{+14} \Omega$ である。

（1）ＭT 法による絶縁劣化診断絶縁物の評価結果 を表 1 に示す。ポリエステル絶縁物の診断に特に有効な 硝酸イオン付着濃度, 硫酸イオン付着濃度, 及び色彩 $\mathrm{b}$ を 測定した ${ }^{(9)}$ 。色彩は Labモードで表した。イオン付着量は $1.02 \times 10^{-2} \sim 9.08 \times 10^{-2} \mathrm{mg} / \mathrm{cm}^{2}$, 色彩 $\mathrm{b}$ は $-0.34 \sim-0.53$ であった。これらの評価結果を MT 法で解析し湿度 $50 \% \mathrm{RH}$ における絶縁物の表面抵抗率を求めた結果, $3.89 \times 10^{+8} \sim$ $7.74 \times 10^{+8} \Omega$ であった（表 2 )。なお, 硝酸イオン, 硫酸イ オン, 色彩 $\mathrm{b}$, 及び表面抵抗率実測值の变動係数はそれぞ れ $0.63,0.40,0.32$, 及び 0.39 であり, 表面抵抗率と同レ ベルのばらつきでイオン, 色彩 $\mathrm{b}$ の測定が可能であること を確認している。

（2）絶縁物の余寿命診断新品時と診断時の表面抵 抗率を結び, 湿度 50\%RH での表面抵抗率低下の時間依存性 直線を得た。絶縁物の形状等から求めた放電が発生する表面 抵抗率 (放電間值) は $2.0 \times 10^{+7} \Omega$ であった。湿度 $100 \% \mathrm{RH}$ で表面抵抗率が $2.0 \times 10^{+7} \Omega$ であるとき, 湿度補正式より

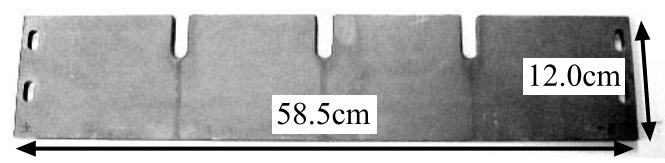

図 10 ポリエステル絶縁物の外観

Fig. 10. Observation results of polyester insulator. 
表 1 絶縁物の評価結果

Table 1. Evaluation results of insulators.

\begin{tabular}{clll}
\hline Sample & $\begin{array}{l}\text { Nitric } \\
\text { acid ion } \\
\left(\mathrm{mg} / \mathrm{cm}^{2}\right)\end{array}$ & $\begin{array}{c}\text { Sulfuric } \\
\text { acid ion } \\
\left(\mathrm{mg} / \mathrm{cm}^{2}\right)\end{array}$ & $\begin{array}{l}\text { Color- } \\
\text { ation b } \\
(\text { a.u. })\end{array}$ \\
\hline A & $1.02 \times 10^{-2}$ & $7.29 \times 10^{-2}$ & -0.53 \\
B & $1.22 \times 10^{-2}$ & $6.43 \times 10^{-2}$ & -0.34 \\
C & $1.14 \times 10^{-2}$ & $9.08 \times 10^{-2}$ & -0.48 \\
\hline
\end{tabular}

表 2 余寿命推定結果

Table 2. Presumption results of remaining service life for insulators.

\begin{tabular}{ccc}
\hline Sample & $\begin{array}{c}\text { Surface } \\
\text { resistivity } \\
(\Omega: 50 \% \text { RH })\end{array}$ & $\begin{array}{c}\text { Remaining } \\
\text { service life } \\
\text { (years) }\end{array}$ \\
\hline A & $6.31 \times 10^{+8}$ & -0.9 \\
B & $7.74 \times 10^{+8}$ & -0.8 \\
C & $3.89 \times 10^{+8}$ & -1.1 \\
\hline
\end{tabular}

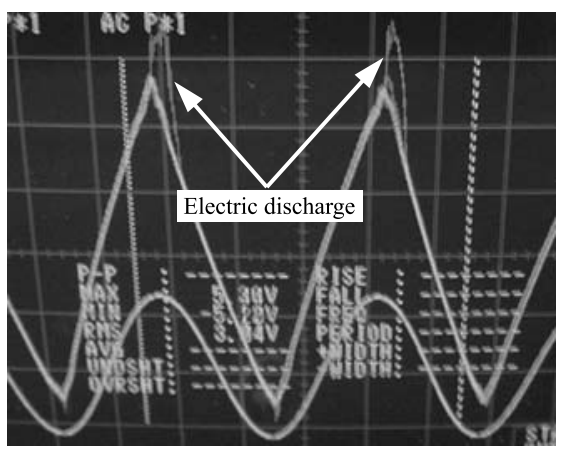

図 11 放電発生の検証試験結果

Fig. 11. Check examination results of electric discharge initiation.

湿度 $50 \% \mathrm{RH}$ では $1.5 \times 10^{+9} \Omega$ であるから，表面抵抗率低 下の時間依存性直線において湿度 $100 \% \mathrm{RH}$ での放電閾值は $1.5 \times 10^{+9} \Omega$ となる。 $1.5 \times 10^{+9} \Omega$ と直線が交差する年数 を求めることにより湿度 $100 \%$ RH での余寿命を算出した。 余寿命診断結果を表 2 に示す。サンプル A が -0.9 年, B が -0.8 年, $\mathrm{C}$ が -1.1 年であり，いずれのサンプルも寿命 を迎えていると考えられる。なお，イオン等の測定誤差に よる余寿命のばらつきは, サンプル A， B， C とも \pm 0.5 年 であった。

$\langle\mathbf{4} \cdot \mathbf{6} \cdot \mathbf{2}\rangle$ 電圧印加試験による余寿命の検証推定し た絶縁物の余寿命診断結果を検証するために, 電圧 $3.45 \mathrm{kV}$, 湿度 $100 \% \mathrm{RH}$ の条件で電圧印加試験を行った。これらの サンプルの余寿命推定值は $-1.1 \sim-0.8$ 年であり寿命を迎 えているため, 電圧印加試験により放電が発生すると考え られる。電圧印加試験の漏れ電流波形を図 11 に示す。い ずれのサンプルでも放電を観察したことから，本技術によ る余寿命推定を検証することができた。

\section{5. まとめ}

本論文では受配電設備の寿命を決定する重要部品である 絶縁物に着目し，余寿命診断技術を開発した。得られた結 果を以下にまとめる。

（1） MT 法で推定した表面抵抗率と実験室で測定した 表面抵抗率の実測值は良好な相関を示したことから, 絶縁 物表面のイオン付着量等より湿度 $50 \% \mathrm{RH}$ における表面抵 抗率の算出が可能であることを明確にした。

（2）ガウス分布関数を用いた湿度補正式により，ある 湿度における絶縁物の表面抵抗率が分かれば，任意の湿度 における表面抵抗率を求めるできることが分かった。

(3) 放電開始条件の数值化を行い各種パラメーターと の関係を数式化した結果, 課電電圧, 絶縁物の形状等から 放電閾值が算出可能であることを明確にした。

（4）絶縁物の経年劣化は経過年数にリニアー值, 表面 抵抗率に対数值をとると直線関係になることから，新品時 と診断時の絶縁物の表面抵抗率 $(50 \% \mathrm{RH})$ を結んだ直線が 放電閾值と交差する年数を求めることにより余寿命の推定 が可能であることを明確にした。また，湿度補正式を用い ることにより任意の湿度での余寿命推定が可能になった。

（５）実験室で行った電圧印加による放電発生の確認試 験と余寿命推定結果に相関性があり，本手法で余寿命診断 が可能であることを検証することができた。

謝 辞

絶縁物をご提供頂きました新日本石油（株）水島精油所 殿に感謝致します。

(平成 19 年 1 月 15 日受付)

\section{文献}

（1）河村達雄 ・田中祀捷：電気設備の診断技術, 電気学会編, オーム社 (2003)

（2）設備診断更新技術調查専門委員会編：「工場電気設備の診断・更新 技術」, 電気学会技術報告, No.831 (2001)

(3) 絶縁材料の劣化と機器・ケーブルの絶縁劣化判定調査専門委員会編： 「絶縁材料の劣化と機器・ケーブルの絶縁劣化判定の実態」, 電気学 会技術報告, No.752 (2000)

(4) C.T. Dervos, C.D. Paraskevas, P. Skafidas, and P. Vassiliou: "Dielectric Characterization of Power Transformer Oils as a Diagnostic Life Prediction Method", IEEE Elect. Insul. Mag., Vol.21, No.1, pp.11-19 (2005)

(5) J. Katagiri, Y. Takezawa, and K. Yamanaka: "Deterioration Diagnosis for Molded Power Transformers by Optical Fiber Sensor", IEEJ Trans. FM, Vol.123, No.7, pp.657-662 (2003-7) (in Japanese)

片桐純一・竹澤由高・山中功治：「モールド変圧器の光診断法による 熱劣化診断技術」, 電学論 A, 123, 7, pp.657-662 (2003-7)

(6) M. Hatanaka, M. Nakade, T. Hirose, S. Sugimoto, and Y. Namiki: "Service Life Estimation Technique of Oxidized XLPE Cable", IEEJ Trans. PE, Vol.123, No.12, pp.1593-1597 (2003-12) (in Japanese)

畑中正樹 - 中出雅彦·廣瀬敬史・杉本 修·並木幸彦:「CV ケーブル の酸化劣化寿命診断手法」, 電学論 B, 123, 12, pp.1593-1597 (2003-12)

(7) A. Cavallini, D. Fabiani, G. Mazzanti, and G.C. Montanari: "Life Model Based on Space-Charge Quantities for HVDC Polymeric Cables Sujected to Voltage-Polarity Inversions", IEEE Trans. Dielectr. Electr. Insul., Vol.9, No.4, pp.514-523 (2005)

(8) H. Okazawa and S. Miki: "Degradation Diagnosis and Life-Expectancy Presumption Technology of the Power Distribution System by the MahalanobisTaguchi Method", The Paper of Technical Meeting on Public Plant Engineering, IEE Japan, PPE-06-11, pp.19-24 (2006) (in Japanese) 
岡澤 周・三木伸介：「MT 法によるスイッチギヤ絶縁物の劣化診断・ 余寿命推定技術」, 電気学会公共施設研資, PPE-06-11, pp.19-24 (2006)

(9) S. Miki and H. Okazawa: "Diagnosis of the Degradation of Insulating Material Using the Mahalanobis-Taguchi System Method", The Paper of Technical Meeting on General Industry, IEE Japan, GID-01-24, pp.21-26 (2001) (in Japanese)

三木伸介・岡澤 周:「絶縁劣化診断へのマハラノビス・タグチシス テム法の適用」, 電気学会一般産業研資, GID-01-24, pp.21-26 (2001)

(10) G.C. Stone: "Partial Discharge Diagnostics and Electrical Equipment Insulation Condition Assessment", IEEE Trans. Dielectr. Electr. Insul., Vol.12, No.5, pp.891-903 (2005)

(11) T. Watanabe, I. Kasama, H. Ishii, and Y. Takagi: "Partial Discharge Detector for Substation Predictive Maintenance System", T. IEE Japan, Vol.116-B, No.1, pp.65-73 (1996-1) (in Japanese) 渡部㴊士・笠間一郎·石井秀和・高木義之:「受配電設備䛦断用部分 放電検出装置」, 電学論 B, 116, 1, pp.65-73 (1996-1)

（12）田口玄一・兼高達戴:「MT システムにおける技術開発」, 品質工学応 用講座, 日本規格協会 (2002)

(13) M. Qunigoh: "An Introduction to Mahalanobis Distance for MTS Methods", Quality Engineering, Vol.9, No.1, pp.13-21 (2001-1) (in Japanese) 救仁郷 誠：「マハラノビスの距離 入門」,品質工学, 9, 1, pp.13-21 (2001-1)

(14) S. Hirabayashi, T. Hasegawa, Y. Shibuya, and Y. Inuishi: "Estimation of Void Dimension Distribution in Insulation of Rotating Machine Coil", $T$. IEE Japan, Vol.94-A, No.8, pp.317-333 (1974-8) (in Japanese) 平林庄司・長谷川武敏・渋谷義一・犬石嘉雄 : 「回転機コイルのボイ ド分布推定法」, 電学論 A, 94, 8, pp.317-333 (1974-8)

三木 伸 介（正員） 1993 年 3 月大阪府立大学大学院工学研

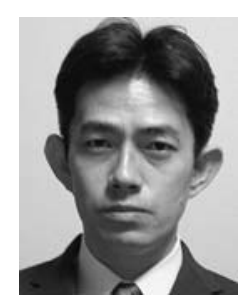

究科修士課程修了。同年 4 月三菱電機 (株) 入社。 先端技術総合研究所において, 主として有機材料 や潤滑油の評価・診断に関する研究に従事。
岡 澤

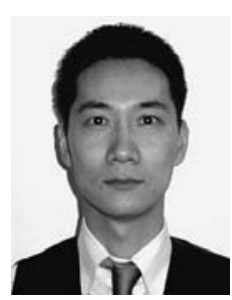

周（非会員） 1998 年 3 月姫路工業大学工学部機械 工学科を卒業。同年 4 月三菱電機（株）入社。現 在, 三菱電機 (株) 受配電システム製作所 受配計 課に勤務し，主に予防保全技術開発，予防保全活 動に従事。

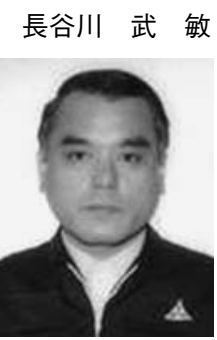

（正員） 1968 年 3 月三重県立津工業高等学校電 気科卒業。同年 4 月三菱電機（株）入社。以来, 同社, 中央研究所にて, 発電機, GIS, 変圧器な どの電力機器の絶縁技術開発に従事。現在，同社 先端技術総合研究所 電機システム技術部サージ . 高電界グループにて, パワーエレクトロニクス機 器の絶縁技術開発に従事。工博。1975 年電気学 会論文賞受賞。

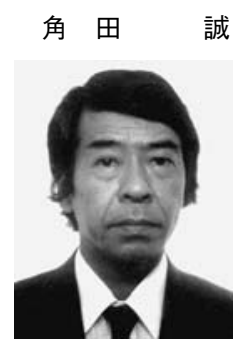

誠（非会員） 1972 年 3 月大阪大学理学部高分子学 科卒。同年 4 月三菱電機 (株) 入社。 2006 年 3 月 まで先端技術総合研究所勤務。同年 4 月から (株) エムテック本社勤務。海外特許事務担当。

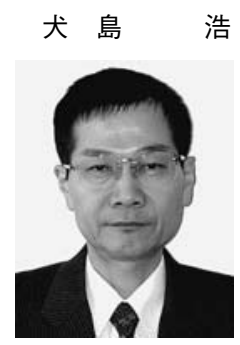

浩

1975 年北海道大学工学部電子工学科卒。 同年, 三菱電機 (株) 入社。同社中央研究所, 産業 システム研究所に所属。プラント・機器の診断 · 監視・制御に関する研究に従事。2002 年 4 月か ら, 早稲田大学大学院情報生産システム研究科・ 教授。工学博士。1991 年電気学会論文賞受賞。電 気学会, 日本原子力学会, 計測自動制御学会, 情 報処理学会各会員。 